\begin{tabular}{|c|l|}
\hline Title & K-edge X-ray absorption fine structure analysis of Pt/A u core shell electrocatalyst : evidence for short Pt-Pt distance \\
\hline Author(s) & $\begin{array}{l}\text { Kaito, Takahiro; Mitsumoto, Hisashi; Sugawara, Seiho; Shinohara, Kazuhiko; Uehara, Hiromitsu; A riga, Hiroko; } \\
\text { Takakusagi, Satoru; Hatakey ama, Y oshikiyo; Nishikawa, Keiko; A sakura, Kiy otaka }\end{array}$ \\
\hline Citation & $\begin{array}{l}\text { Journal of physical chemistry. C, 118(16), 8481-8490 } \\
\text { https://doi.org/10.1021/jp501607f }\end{array}$ \\
\hline Issue Date & 20140424 \\
\hline Doc URL & http://hdl.handle.net/2115/56614 \\
\hline Type & article \\
\hline File Information & jp501607f.pdf \\
\hline
\end{tabular}

Instructions for use 


\title{
K-Edge X-ray Absorption Fine Structure Analysis of Pt/Au Core-Shell Electrocatalyst: Evidence for Short Pt-Pt Distance
}

\author{
Takahiro Kaito, ${ }^{\dagger \neq}$ Hisashi Mitsumoto, ${ }^{\dagger}$ Seiho Sugawara, ${ }^{\dagger}$ Kazuhiko Shinohara, ${ }^{\dagger}$ Hiromitsu Uehara, ${ }^{\S}$
} Hiroko Ariga, ${ }^{\S}$ Satoru Takakusagi, ${ }^{\S}$ Yoshikiyo Hatakeyama, ${ }^{\prime}$ Keiko Nishikawa, ${ }^{\perp}$ and Kiyotaka Asakura* ${ }^{\S}$

${ }^{\dagger}$ Nissan Motor Company, Ltd., Natsushima-cho, Yokosuka-shi, Kanagawa 237-8523, Japan

${ }^{\ddagger}$ Department of Quantum Chemistry and Technology, Graduate School of Engineering, and ${ }^{\S}$ Catalysis Research Center, Hokkaido University, Kita 21 Nishi 10, Kita-ku, Sapporo, Hokkaido 001-0021, Japan

"Department of Physics, College of Humanities and Sciences, Nihon University 3-25-40 Sakura Josui, Setagaya-ku, Tokyo 156-8550, Japan

${ }^{\perp}$ Department of Nanoscience and Technology Graduate School of Advanced Integrated Science, Chiba University, 1-33 Yayoi, Inage, Chiba 262-8522, Japan

Supporting Information

ABSTRACT: A carbon-supported Pt-shell Au-core electrocatalyst $(\mathrm{Pt} / \mathrm{Au} / \mathrm{C})$ was prepared by sequential deposition of $\mathrm{Pt}$ ions on the surface of Au nanoparticles supported on carbon. The area-specific activity of the oxygen reduction reaction (ORR) for the prepared $\mathrm{Pt} / \mathrm{Au} / \mathrm{C}$ in $0.1 \mathrm{M} \mathrm{HClO}_{4}$ aqueous solution was approximately 2 times higher than that for a commercial carbon-supported $\mathrm{Pt}$ electrocatalyst $(\mathrm{Pt} / \mathrm{C})$. The core-shell structure was confirmed using electrochemical methods and $\mathrm{Pt}$ and $\mathrm{Au}$ K-edge $\mathrm{X}$-ray absorption fine structure (XAFS) analysis. XAFS analyses indicated that the $\mathrm{Pt}-\mathrm{Pt}$ bond distance for the $\mathrm{Pt} / \mathrm{Au} / \mathrm{C}$ catalyst was shorter than that for $\mathrm{Pt}$ foil and the $\mathrm{Pt} / \mathrm{C}$ catalyst. In addition, the $\mathrm{Au}-\mathrm{Au}$ distance was much shorter than that for Au foil. The reason for the high ORR activity of $\mathrm{Pt} / \mathrm{Au} / \mathrm{C}$ is considered to be shorter $\mathrm{Pt}-\mathrm{Pt}$ bond distance as compared to that of $\mathrm{Pt} / \mathrm{C}$.
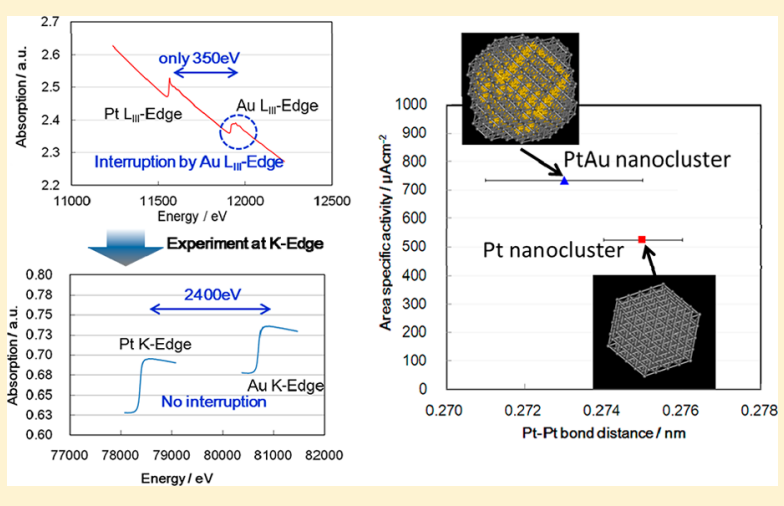

\section{INTRODUCTION}

Polymer electrolyte fuel cells (PEFCs) have potential as nextgeneration power sources for vehicles because they do not emit greenhouse gases during operation. However, there are many issues that must be resolved before PEFCs can be adopted worldwide and fuel cell electric vehicles (FCEVs) are realized. These issues include the low power density of the FC stack, low efficiency of the entire power-train system, low durability under a wide range of operating conditions and environments, and cost reduction. ${ }^{1}$ In particular, to increase the power density and reduce costs, it is essential to improve the mass-specific activity of the Pt electrocatalyst in the FC for the oxygen reduction reaction (ORR). ${ }^{2}$ Therefore, the structure of the Pt electrocatalyst and the reaction mechanism must be studied to understand ORR catalysis at the atomic level. ${ }^{3-7} \mathrm{X}$-ray absorption fine structure (XAFS) is a powerful technique that can be used to study dynamic structural changes in an electrochemical environment. The XAFS method provides information on local structures and electronic states, such as valence states and the $\mathrm{d}$ vacancies of $5 \mathrm{~d}$ transition metal atoms. In situ XAFS has been employed to investigate catalysts, ${ }^{8}$ and such studies have revealed catalytic properties and reaction mechanisms based on dynamic structural changes ${ }^{9-11}$ using actual fuel cell stacks ${ }^{12-15}$ and three-electrode electrochemical cells. $^{16-24}$

In recent years, core-shell type electrocatalysts have drawn wide attention for improvement in the mass-specific activity of $\mathrm{Pt}^{25}$ One effective core-shell electrocatalyst consists of a Au core and a Pt shell supported on a carbon substrate. ${ }^{6,26-33}$ In $\mathrm{Pt} / \mathrm{Au}$ core-shell electrocatalysts, both the mass-specific activity and the area-specific activity are increased with respect to the $\mathrm{Pt}$ nanoparticle electrocatalyst, which indicates the effectiveness of the core-shell structure to not only increase the $\mathrm{Pt}$ fraction on the surface of the electrocatalyst particle (geometric effect), but also to modify the Pt electronic state (electronic effect). The latter can be achieved by electron transfer and/or lattice contraction/expansion induced by interactions between the $\mathrm{Au}$ core and the $\mathrm{Pt}$ shell. However, it is difficult to directly determine the core-shell structure if the Pt shell thickness is as small as one or two monolayers. Considering the Au lattice, the $\mathrm{Pt}-\mathrm{Pt}$ distance of the Pt shell in a $\mathrm{Pt} / \mathrm{Au}$ core-shell electrocatalyst is expected to be longer than

Received: February 14, 2014

Revised: March 30, 2014

Published: April 1, 2014 
that in a simple Pt electrocatalyst. Surface X-ray diffraction analysis has revealed that the $\mathrm{Pt}-\mathrm{Pt}$ distance in a $\mathrm{Pt}$ monolayer deposited on the $\mathrm{Au}(111)$ surface is elongated. ${ }^{34}$ Core-shell structures and lattice mismatch can be determined directly using XAFS. Although XAFS is the most suitable technique to investigate the core-shell structures of nanoclusters and their bond distances, interference between the $\mathrm{Pt}$ and $\mathrm{Au} \mathrm{L}_{\mathrm{III}} \mathrm{X}$-ray absorption edges hinders XAFS studies on $\mathrm{Pt}$ and $\mathrm{Au}$ nanoclusters. The separation of the $\mathrm{Pt}$ and $\mathrm{Au} \mathrm{L}_{\mathrm{III}}$-edges is only approximately $350 \mathrm{eV}$, which results in overlapping of EXAFS oscillation. Hence, reliable curve-fitting analysis of the $\mathrm{Pt}$ and $\mathrm{Au} \mathrm{L}_{\mathrm{III}}$ edges becomes difficult. ${ }^{30,35,36}$

If $\mathrm{Pt}$ and $\mathrm{Au} \mathrm{K}$-edge XAFS analyses can be performed, we can obtain well-separated $\mathrm{Pt}$ and $\mathrm{Au}$ spectra (Pt and $\mathrm{Au}$ K-edges are located at 78.4 and $80.7 \mathrm{keV}$, respectively), although this had been considered to be impossible due to machine limitations and finite lifetime broadening. After Ce K-edge XAFS was shown to be possible, ${ }^{37}$ the extension of K-edge XAFS measurements to higher energies has progressed. Nishihata et al. reported Pt K-edge XAFS measurements, ${ }^{38}$ and Nagamatsu et al. conducted ex situ K-edge XAFS measurements on fuel cell $\mathrm{Pt} / \mathrm{Au}$ catalysts. ${ }^{39}$ We have previously demonstrated that in situ $\mathrm{Pt}$ and $\mathrm{Au}$ K-edge XAFS measurements are both possible and effective for the investigation of $\mathrm{Pt} / \mathrm{Au}$ core-shell electrocatalysts under operating conditions. ${ }^{40}$

Recently, Inaba and co-workers claimed that the simple reaction of a Pt precursor with $\mathrm{Au}$ nanoparticles on $\mathrm{C}$ without a reducing agent and under inert gas flow allows the selective deposition of $\mathrm{Pt}$ on the $\mathrm{Au}$ nanoparticles to form core-shell structures. ${ }^{32,33}$ In this Article, Pt/Au core-shell structures on the carbon were prepared using a method similar to that reported by Inaba and co-workers, ${ }^{32,33}$ and the resultant carbon-supported $\mathrm{Au}-\mathrm{Pt}$ electrocatalyst was characterized using in situ Pt and Au K-edge XAFS spectroscopic measurements together with physical and electrochemical analyses. We discussed the structural parameters obtained by curve fitting and the origin of the enhanced area-specific activity of $\mathrm{Pt} / \mathrm{Au} / \mathrm{C}$.

\section{MATERIALS AND METHODS}

2.1. Preparation of $\mathrm{Pt} / \mathrm{Au} / \mathrm{C}$ Core-Shell Electrocatalyst. The following procedure was used to prepare the $\mathrm{Pt} / \mathrm{Au} / \mathrm{C}$ electrocatalyst samples. The method for the deposition of $\mathrm{Pt}$ on the $\mathrm{Au}$ nanocluster was similar to that proposed by Inaba and co-workers. ${ }^{32,33} \mathrm{Au}$ nanoclusters were first prepared using the sputter-deposition-onto-ionic-liquid method, ${ }^{41-43}$ which produces small homogeneous Au nanoclusters. A sputter coater (SC-704, Sanyu Electron; acceleration voltage $=1 \mathrm{kV}$, ion current $=20 \mathrm{~mA}$ ) was used to sputter $\mathrm{Au}$ into $3 \mathrm{~mL}$ of ionic liquid (1-butyl-3-methylimidazolium tetrafluoroborate; $\mathrm{C}_{4} \mathrm{mimBF}_{4}$ ) at $328 \mathrm{~K}$ for $180 \mathrm{~min}$. Next, $0.78 \mathrm{~g}$ of carbon black (XC-72R, Vulcan) was impregnated with the Au nanoparticles in $\mathrm{C}_{4} \mathrm{mimBF}_{4}$ solution for $24 \mathrm{~h}$, followed by stirring in $200 \mathrm{~mL}$ of acetone (Wako, reagent grade) for 10 min to remove $\mathrm{C}_{4} \mathrm{mimBF}_{4}$, and the suspension was then filtered. This washing process was conducted three times to completely remove the ionic liquid. The resultant $\mathrm{Au} / \mathrm{C}$ was dried in an oven at $333 \mathrm{~K}$ for $24 \mathrm{~h}$. $0.1 \mathrm{~g}$ of $\mathrm{Au} / \mathrm{C}$ was suspended in $200 \mathrm{~mL}$ of ultrapure water, and the solution was stirred with a magnetic stirrer for $15 \mathrm{~min}$. The $\mathrm{Au} / \mathrm{C}$-suspended solution was then slowly added to $2 \mathrm{~L}$ of ultrapure water, which was deaerated by bubbling with $\mathrm{N}_{2}$ for $30 \mathrm{~min}$, and $1.0 \mathrm{~g}$ of 7.2 wt $\% \mathrm{H}_{2} \mathrm{PtCl}_{6}$ aqueous solution was added dropwise to the solution; the resulting solution was stirred under a $\mathrm{N}_{2}$ atmosphere for $24 \mathrm{~h}$ at room temperature. The resulting $\mathrm{Pt} /$ $\mathrm{Au} / \mathrm{C}$ was filtered and dried for more than $4 \mathrm{~h}$ at $333 \mathrm{~K}$. Finally, the $\mathrm{Pt} / \mathrm{Au} / \mathrm{C}$ product was scraped from the filter paper, yielding carbon-supported electrocatalyst powder.

Commercially available $\mathrm{Pt} / \mathrm{C}$ was used as a reference (nominal Pt loading 50 wt \%, Ketjen black carbon support; TEC10E50E, Tanaka Kikinzoku Kogyo K.K.).

2.2. Characterization of $\mathrm{Pt} / \mathrm{C}$ and $\mathrm{Pt} / \mathrm{Au} / \mathrm{C}$ Core-Shell Electrocatalysts. The resulting catalysts were characterized using transmission electron microscopy (TEM; HF-2000 field emission TEM Hitachi High-Technologies) with energy dispersive X-ray spectroscopy (EDS; Kevex), inductively coupled plasma-mass spectrometry (ICP-MS; SPS-3520, SII NanoTechnology), and electrochemical methods. TEM was used to determine the particle diameter distribution and average diameter of the electrocatalyst particles. Microscopic elemental analysis of the $\mathrm{Pt} / \mathrm{Au}$ core-shell nanoclusters was conducted using EDS. The amounts of $\mathrm{Pt}$ and $\mathrm{Au}$ electrocatalysts were measured using ICP-MS. The surface composition of $\mathrm{Pt}$ and $\mathrm{Au}$ was derived by electrochemical methods using a three-electrode glass cell and a rotating disk electrode (RDE) measurement apparatus (HZ-5000, Hokuto Denko). For the electrochemical experiments, a reversible hydrogen electrode (RHE) and $\mathrm{Pt}$ mesh were used as the reference and counter electrodes, respectively. Cyclic voltammograms were obtained in deaerated $0.1 \mathrm{M} \mathrm{HClO}_{4}$ solutions. Polarization curves were recorded in an $\mathrm{O}_{2}$-saturated $\mathrm{HClO}_{4}$ solution.

2.3. XAFS Measurements. XAFS experiments were conducted at the X-ray bending magnet beamline BL16B2 of SPring-8. The ring was operated in a top-up mode at $8 \mathrm{GeV}$ with the ring current at $100 \mathrm{~mA}$. The $\mathrm{X}$-ray beam was monochromated using a $\mathrm{Si}(511)$ double crystal monochromator. The incident and transmitted X-ray intensities were monitored using two ionization chambers filled with $\mathrm{Kr}$ before and after the sample, respectively. The setting of the samples in the in situ measurement cells has been described elsewhere. ${ }^{40}$ Prior to the in situ measurements, air was removed by passing pure $\mathrm{N}_{2}$ (99.99995\%) through the electrolyte solution and the XAFS cell for $30 \mathrm{~min}$. During the measurements, $\mathrm{N}_{2}$ gas was continuously flowed over the electrolyte solution to prevent air contamination. The electrode potential was swept cathodically from the rest potential (ca. $1.0 \mathrm{~V}$ ) to $0.05 \mathrm{~V}$ at a slow scan rate $(1 \mathrm{mV} / \mathrm{s})$ to avoid large current and potential variations in the catalyst layer and between the carbon plates. An oxidationreduction cycle (ORC) treatment $(0.05-1.2 \mathrm{~V})$ was conducted three times to remove contamination from the surface of the electrocatalyst. Following the ORC treatments, XAFS measurements were performed at $0.4 \mathrm{~V}$ after holding the electrode potential at $0.4 \mathrm{~V}$ for $10 \mathrm{~min}$. Pt foil, $\mathrm{Au}$ foil, and a $\mathrm{AuPt}$ random alloy foil containing 10 at. \% Pt were also measured as reference samples for curve-fitting analyses.

2.4. XAFS Analyses. XAFS analyses were conducted using the REX2000 (Rigaku) analysis package. The XAFS oscillation $\chi(k)$ was extracted from the observed data $\mu(E)$ by subtracting the smoothly varying part $\mu_{\mathrm{s}}(E)$, which was estimated from cubic splines. ${ }^{44}$ The difference was then normalized using the edge height $\mu_{0}(E):{ }^{45}$

$$
\chi(k)=\frac{\mu(E)-\mu_{s}(E)}{\mu_{0}(E)}
$$


where $k$ is the wavenumber of the photoelectron, which is related to the photon energy $E$, and the threshold energy $E_{0}$, by

$$
k=\frac{1}{\hbar} \sqrt{2 m\left(E-E_{0}\right)}
$$

where $m$ is the mass of the electron. The quantity $k^{3} \chi(k)$ was Fourier transformed to $r$ space, the peak in the transform was filtered, and then an inverse Fourier transform was applied to convert the filtered peak back to $k$ space. The Fourier-filtered data were then analyzed with a curve-fitting technique using the following theoretical XAFS equations: ${ }^{45}$

$$
\begin{aligned}
& k^{3} \chi(k)=\sum_{j} \frac{k_{j}^{2} S_{j} N_{j} F_{j}\left(k_{j}\right) \exp \left(-2 k_{j}^{2} \sigma_{j}^{2}\right)}{r_{j}^{2}} \sin \left(2 k_{j} r_{j}+\varphi_{j}(k)\right) \\
& k_{j}=\left(k^{2}-2 m \Delta E_{0 j} / \hbar^{2}\right)^{1 / 2}
\end{aligned}
$$

In eqs 3 and $4, j$ denotes each coordination shell, $N_{j}$ is the coordination number, $r_{j}$ is the bond length, $\Delta E_{0 j}$ is the difference between the theoretical and experimental threshold energies, and $\sigma_{j}$ is the Debye-Waller factor for the $j$ th coordination shell. The quantities $\phi_{j}(k)$ and $F_{j}(k)$ are phase shifts and amplitude functions, respectively, both of which were derived from FEFF8 calculations. ${ }^{46}$ The amplitude reduction factor $S_{j}$ arises from many-body effects and from inelastic losses during the scattering process. Many-body effects and inelastic losses are dependent on $k$ in opposite ways, so that $S_{j}$ can be regarded as a constant function of $k^{47}$

In the curve-fitting analyses, $S_{j}$ and $\Delta E_{0 j}$ were fixed at the values obtained for the $\mathrm{Pt}$ and $\mathrm{Au}$ foils. The quality of the fit was evaluated according to the $R$-factor:

$$
R=\frac{\sum\left(k^{3} \chi_{\mathrm{obs}}(k)-k^{3} \chi_{\mathrm{calc}}(k)\right)^{2}}{\sum\left(k^{3} \chi_{\mathrm{obs}}(k)\right)^{2}}
$$

where $\chi_{\text {obs }}(k)$ and $\chi_{\text {calc }}(k)$ are the observed and curve-fitted $\chi(k)$ values, respectively.

In the curve-fitting analyses of bimetallic alloys, the following equations must be satisfied within the error: ${ }^{48-50}$

$$
\begin{aligned}
& N_{\mathrm{PtAu}} C_{\mathrm{Pt}}=N_{\mathrm{AuPt}} C_{\mathrm{Au}} \\
& R_{\mathrm{PtAu}}=R_{\mathrm{AuPt}}
\end{aligned}
$$

where $N_{\mathrm{XY}}$ is the coordination number of atom $\mathrm{Y}$ around absorber atom $\mathrm{X}, C_{\mathrm{X}}$ is the mole fraction of atom $\mathrm{X}$, and $R_{\mathrm{XY}}$ is the interatomic distance between atoms $\mathrm{X}$ and $\mathrm{Y}$ on the $\mathrm{X}$ absorption edge. Errors in these structural parameters were determined at the $90 \%$ confidence level by the Hamilton ratio method. ${ }^{51}$

\section{RESULTS}

3.1. Characterization of $\mathrm{Pt} / \mathrm{C}$ and $\mathrm{Pt} / \mathrm{Au} / \mathrm{C}$ Core-Shell Electrocatalysts. Figures $1-3$ show TEM micrographs of $\mathrm{Pt} /$ $\mathrm{C}, \mathrm{Au} / \mathrm{C}$, and $\mathrm{Pt} / \mathrm{Au} / \mathrm{C}$, and their particle diameter distributions. The average diameter of $\mathrm{Pt}$ nanoclusters was estimated to be $2.2 \mathrm{~nm}$ from TEM image analyses of $261 \mathrm{Pt}$ particles. The $\mathrm{Au}$ content of $\mathrm{Au} / \mathrm{C}$ was $8.6 \mathrm{wt} \%$, and the average diameter of the Au nanoclusters was determined to be $2.6 \mathrm{~nm}$ from image analyses of $339 \mathrm{Au}$ particles. Nanoclusters of $\mathrm{Au}$ on carbon had almost the same sizes as that of $\mathrm{Au}$ in solution. The $\mathrm{Pt}$ and $\mathrm{Au}$ contents in the $\mathrm{Pt} / \mathrm{Au} / \mathrm{C}$ catalyst were 4.2 and $3.8 \mathrm{wt} \%$, respectively, as estimated from ICP data. The (a)

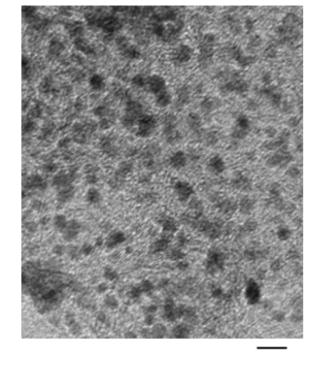

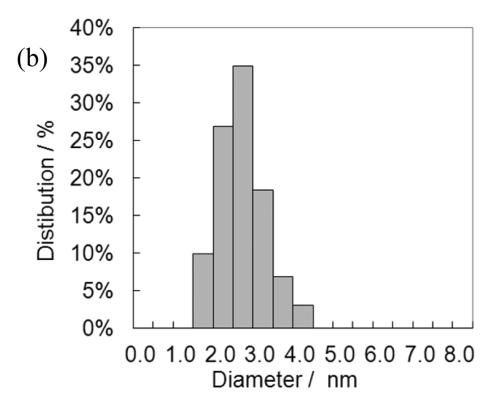

Figure 1. (a) TEM image of commercially available $\mathrm{Pt} / \mathrm{C}$ electrocatalyst, and (b) particle size distribution of $\mathrm{Pt} / \mathrm{C}$ estimated from (a). (a)

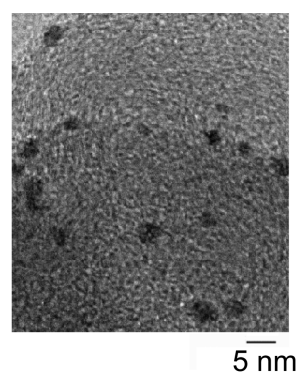

(b)

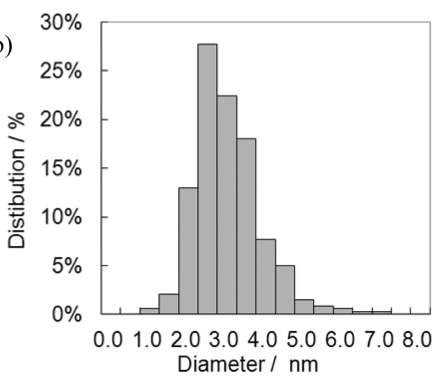

Figure 2. (a) TEM image of the $\mathrm{Au} / \mathrm{C}$ prepared in this study, and (b) particle size distribution of $\mathrm{Au} / \mathrm{C}$ estimated from (a). (a)

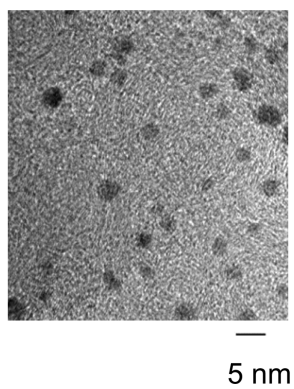

(b)

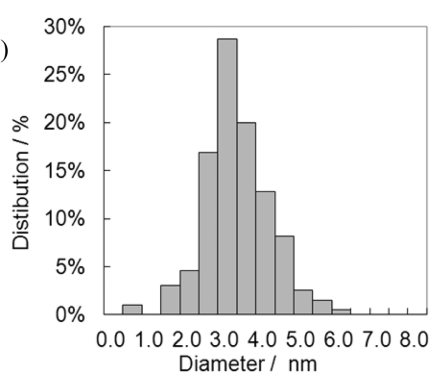

Figure 3. (a) TEM image of the $\mathrm{Pt} / \mathrm{Au} / \mathrm{C}$ prepared in this study, and (b) particle size distribution of $\mathrm{Pt} / \mathrm{Au} / \mathrm{C}$ estimated from (a).

average diameter of $\mathrm{Pt} / \mathrm{Au}$ nanoclusters was estimated to be 3.0 $\mathrm{nm}$ from TEM image analyses of 195 nanoclusters. Comparison of the average diameter of $\mathrm{Au} / \mathrm{C}$ with that of $\mathrm{Pt} / \mathrm{Au} / \mathrm{C}$ indicated that the thickness of the Pt shell would be two atomic layers.

The $\mathrm{Pt} / \mathrm{Au} / \mathrm{C}$ was dispersed in a solvent of ultrapure water and Nafion by ultrasonication for $30 \mathrm{~min}$. The suspension was deposited on the precleaned glassy carbon substrate of the RDE to satisfy the $5.0 \mu \mathrm{g}-\mathrm{Pt} / \mathrm{cm}^{2} \mathrm{Pt}$ loading and allowed to dry at 60 ${ }^{\circ} \mathrm{C}$. Figure 4 shows cyclic voltammograms for $\mathrm{Pt} / \mathrm{Au} / \mathrm{C}$ recorded over a potential range of $0-1.6 \mathrm{~V}$ at a sweep rate of $50 \mathrm{mV} / \mathrm{s}$. The potential was first swept anodically up to $1.6 \mathrm{~V}$, and then the sweep direction was reversed. A small $\mathrm{AuO}$ reduction peak was observed at $1.2 \mathrm{~V}$ in the cathodic sweep. The total surface area of the $\mathrm{Pt} / \mathrm{Au}$ core-shell was the sum of the $\mathrm{Pt}$ surface area, $S_{\mathrm{Pt}}$ and the $\mathrm{Au}$ surface area, $S_{\mathrm{Au}}$. The percentage of Pt coverage was calculated using $S_{\mathrm{Pt}} /\left(S_{\mathrm{Pt}}+S_{\mathrm{Au}}\right)$ and was $0.76 \mathrm{~cm}^{2}$, as calculated from the hydrogen underpotential deposition $\left(H_{\mathrm{UPD}}\right)$ charge of Figure 4, divided by the hydrogen desorption and/or adsorption density on polycrystalline $\mathrm{Pt}\left(210 \mu \mathrm{C} / \mathrm{cm}^{2}\right) .{ }^{52} S_{\mathrm{Au}}$ was determined to be $0.11 \mathrm{~cm}^{2}$ from the $\mathrm{AuO}$ reduction charge around $1.2 \mathrm{~V}$ in Figure 4, 


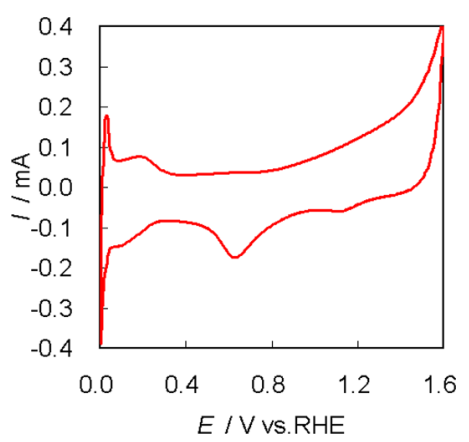

Figure 4. Cyclic voltammogram for the $\mathrm{Pt} / \mathrm{Au} / \mathrm{C}$ prepared core-shell electrocatalyst measured at a sweep rate of $50 \mathrm{mV} / \mathrm{s}$.

divided by $386 \mu \mathrm{C} / \mathrm{cm}^{2} .53$ The Pt coverage percentage was approximately $88 \%$. The electrochemical surface area (ECSA) was calculated to be $71.9 \mathrm{~m}^{2} / \mathrm{g}$-Pt from $S_{\mathrm{pt}}$ and the Pt loading on the RDE.

3.2. ORR Activity of $\mathrm{Pt} / \mathrm{Au} / \mathrm{C}$ Core-Shell Electrocatalysts. Figure 5a shows polarization curves measured with the $\mathrm{RDE}$ for the $\mathrm{Pt} / \mathrm{Au} / \mathrm{C}$ electrocatalyst in $0.1 \mathrm{M} \mathrm{HClO}_{4}$ solution purged with $99.99 \% \mathrm{O}_{2}$ at various rotation speeds and at a sweep rate of $10 \mathrm{mV} / \mathrm{s}$. The Pt loading was $5.0 \mu \mathrm{g}-\mathrm{Pt} / \mathrm{cm}^{2}$.

Figure $5 \mathrm{~b}$ shows Koutecky-Levich plots, that is, the inverse current density $(1 / j)$ plotted as a function of the inverse square root of the rotation rate $\left(\omega^{1 / 2}\right)$ using the data in Figure 5a. The linearity and parallelism of these plots indicate first-order kinetics with respect to molecular oxygen. ${ }^{54}$ The specific activity of the $\mathrm{Pt} / \mathrm{Au} / \mathrm{C}$ electrocatalyst was evaluated at an electrode potential of $0.9 \mathrm{~V}$ and was $571 \mu \mathrm{A} / \mathrm{cm}^{2}$, so that the mass-specific activity was $411 \mathrm{~A} / \mathrm{g}$. In contrast, the area-specific and mass-specific activities for the commercial Pt/C electrocatalyst were $298 \mu \mathrm{A} / \mathrm{cm}^{2}$ and $251 \mathrm{~A} / \mathrm{g}$, respectively. Thus, the area-specific and mass-specific activities of the $\mathrm{Pt} / \mathrm{Au} / \mathrm{C}$ electrocatalyst were 1.9 times and 1.6 times larger than those of the $\mathrm{Pt} / \mathrm{C}$ electrocatalyst, respectively.

3.3. XAFS Analysis. 3.3.1. Reference Foils. Figure 6 shows the Pt K-edge XAFS spectrum and its oscillations for Pt foil. Although the Pt K-edge XAFS spectrum has a smooth edge jump due to lifetime broadening, XAFS oscillations could be observed after the appropriate background was removed, as shown in Figure 6b. The K-edge data were analyzed on the basis of the FEFF-derived phase shift and amplitude functions. ${ }^{46}$ The resulting values for the $\mathrm{Pt}-\mathrm{Pt}$ bond distance, coordination number, and Debye-Waller factor are shown in
Table 1. Because Au and Pt have a face-centered cubic (fcc) structure, the coordination number of the first nearest neighbor atoms is 12 . To obtain this coordination number, the mean free path was set to $0.24 \mathrm{~nm}$, which was shorter than the mean free path of $0.65 \mathrm{~nm}$ in the $\mathrm{L}_{\mathrm{III}}$-edge XAFS, due to the lifetime broadening effect as reported by Nishihata et al. ${ }^{38}$ This free path value $(0.24 \mathrm{~nm})$ was used for further curve fitting of the $\mathrm{Pt}$ K-edge data.

Figure 7a and $\mathrm{b}$ shows the Au K-edge XAFS spectrum and its oscillations for Au foil. A smooth edge jump was observed, as for the Pt foil in Figure 6a. The K-edge data were analyzed on the basis of the FEFF-derived phase shift and amplitude functions. ${ }^{46}$ The resulting values for the $\mathrm{Au}-\mathrm{Au}$ bond distance, coordination number, and Debye-Waller factor are shown in Table 1 . The mean free path was set to $0.21 \mathrm{~nm}$ to give a coordination number of 12 .

Comparing the $\mathrm{Pt}-\mathrm{Pt}$ distances for the $\mathrm{K}$-edge and $\mathrm{L}_{\mathrm{III}}$-edge shown in Table 1, the Pt-Pt distance of the $\mathrm{L}_{\mathrm{II}^{-}}$-edge was 0.003 $\mathrm{nm}$ shorter than that of the K-edge. The same tendency was also observed in the $\mathrm{Au}-\mathrm{Au}$ bond distances. Accordingly, the bond distance obtained from curve fitting of the K-edge was considered to be longer than that derived from the $\mathrm{L}_{\mathrm{III}}$-edge, although the reason for this discrepancy remains unknown.

Figure $8 \mathrm{a}$ and $\mathrm{b}$ shows the Pt K-edge XAFS spectrum and its oscillations for $\mathrm{Au}-\mathrm{Pt}(1 / 9)$ foil. Although the phase shifts $\phi_{j}(k)$ and amplitude functions $F_{j}(k)$ of $\mathrm{Pt}$ and $\mathrm{Au}$ atoms are so close that discrimination is difficult, the metallic radii of $\mathrm{Pt}$ and $\mathrm{Au}$ differ by about $0.005 \mathrm{~nm}$; this is sufficient to create a phase difference in the oscillations, so that $\mathrm{Pt}-\mathrm{Pt}$ and $\mathrm{Pt}-\mathrm{Au}$ contributions can be distinguished with careful analysis. A one-shell curve fitting for the $\mathrm{Pt}-\mathrm{Au}$ bond was first conducted for the $\mathrm{Au}-\mathrm{Pt}$ foil in an attempt to distinguish $\mathrm{Pt}$ and $\mathrm{Au}$ by the difference in bond distance. The resulting curve-fitting parameters are shown in Table 1. The coordination number was less than 12, probably because residual $\mathrm{Pt}-\mathrm{Pt}$ interactions were neglected. A two-shell curve fit was then conducted using different bond distances to separate the $\mathrm{Pt}-\mathrm{Pt}$ and $\mathrm{Pt}-\mathrm{Au}$ shells. In the two-shell fitting, the value of $\Delta E_{0}$ for the $\mathrm{Pt}-\mathrm{Pt}$ bond was fixed at the value for Pt foil. Consequently, a total coordination number of almost 12 was obtained. The $\mathrm{Pt}-\mathrm{Au}$ bond distance obtained from the curve fit was between the Pt$\mathrm{Pt}$ and $\mathrm{Au}-\mathrm{Au}$ bond distances for the pure foils.

3.3.2. Pt/C Electrocatalyst. Figures 9 and 10 show the Pt Kedge and $\mathrm{L}_{\mathrm{III}}$-edge absorption spectra and the $k^{3}$-weighted XAFS oscillations for $\mathrm{Pt} / \mathrm{C}$, respectively. The oscillations for $\mathrm{Pt} / \mathrm{C}$ were smaller than those for the $\mathrm{Pt}$ foil, which indicates a
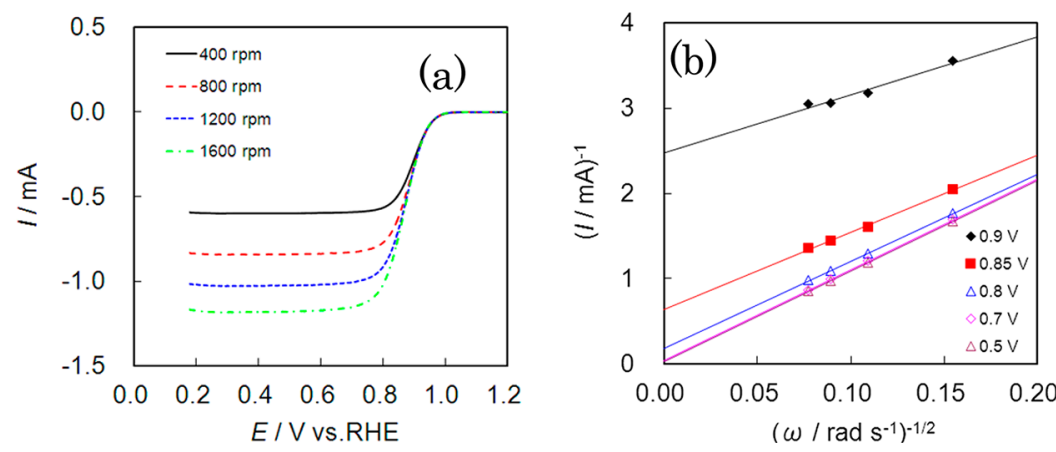

Figure 5. (a) ORR polarization curves measured using a $\mathrm{RDE}$ for $\mathrm{Pt} / \mathrm{Au} / \mathrm{C}$ core-shell electrocatalyst in $0.1 \mathrm{M} \mathrm{HClO}_{4}$. Black solid line: $400 \mathrm{rpm}$. Red broken line: $800 \mathrm{rpm}$. Blue dotted line: $1200 \mathrm{rpm}$. Green chain line: $1600 \mathrm{rpm}$. (b) Koutecky-Levich plots for ORR obtained from (a). Applied voltages were following. $\diamond: 0.9$ V. Red $\mathbf{\square}: 0.85$ V. Blue $\triangle$ : 0.8 V. Purple $\diamond: 0.7$ V. Brown $\triangle: 0.5$ V. 

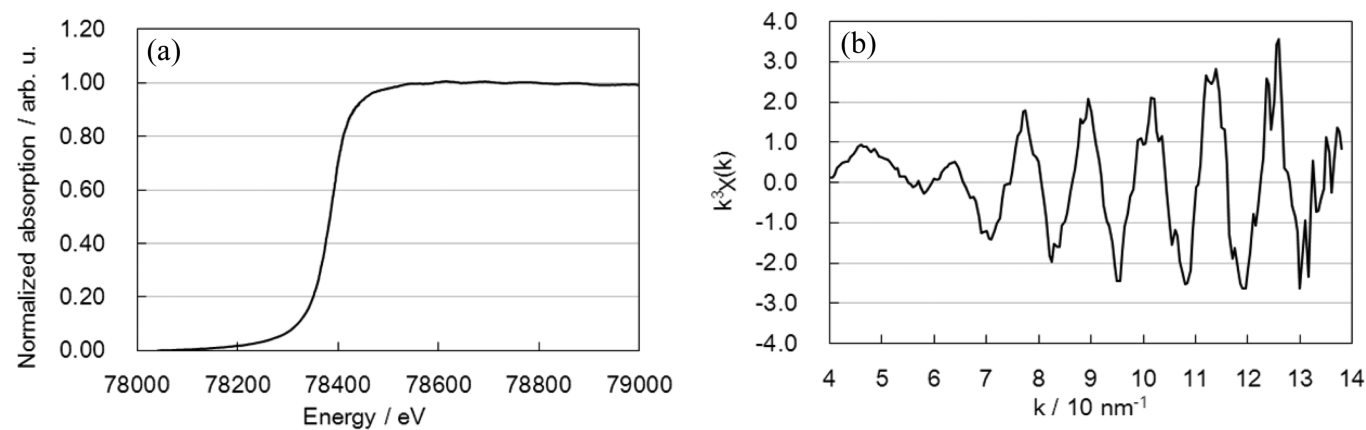

Figure 6. (a) Pt K-edge spectrum for Pt foil, and (b) $k^{3}$-weighted XAFS oscillation after background subtraction and normalization of spectrum (a).

\section{Table 1. Curve-Fitting Results for Reference Foils}

\begin{tabular}{llllccc}
\multicolumn{1}{c}{ sample } & \multicolumn{1}{c}{ edge } & & bond & coordination number $^{a}$ & inter atomic distance/nm & Debye-Waller factor/nm \\
Pt foil & $\mathrm{Pt}-\mathrm{L}_{\mathrm{III}}$ & & $\mathrm{Pt}-\mathrm{Pt}$ & $(12)$ & $0.275 \pm 0.001$ & $0.0071 \pm 0.0004$ \\
& $\mathrm{Pt}-\mathrm{K}$ & & $\mathrm{Pt}-\mathrm{Pt}$ & $(12)$ & $0.278 \pm 0.001$ & $0.0065 \pm 0.0004$ \\
$\mathrm{Au}$ foil & $\mathrm{Au}-\mathrm{L}_{\mathrm{III}}$ & & $\mathrm{Au}-\mathrm{Au}$ & $(12)$ & $0.284 \pm 0.001$ & $0.0080 \pm 0.0002$ \\
& $\mathrm{Au}-\mathrm{K}$ & & $\mathrm{Au}-\mathrm{Au}$ & $(12)$ & $0.286 \pm 0.001$ & $0.0080 \pm 0.0005$ \\
$\mathrm{Au}-\mathrm{Pt}$ (1/9) foil & one shell & $\mathrm{Pt}-\mathrm{K}$ & $\mathrm{Pt}-\mathrm{Au}$ & $10.5 \pm 1.3$ & $0.282 \pm 0.001$ & $0.0078 \pm 0.0003$ \\
& two shell & $\mathrm{Pt}-\mathrm{K}$ & $\mathrm{Pt}-\mathrm{Pt}$ & $1.2 \pm 0.7$ & $0.277 \pm 0.003$ & $0.0072 \pm 0.0023$ \\
& & $\mathrm{Pt}-\mathrm{K}$ & $\mathrm{Pt}-\mathrm{Au}$ & $10.8 \pm 1.1$ & $0.283 \pm 0.001$ & $0.0077 \pm 0.0003$
\end{tabular}

${ }^{a}$ Values in parentheses were fixed.
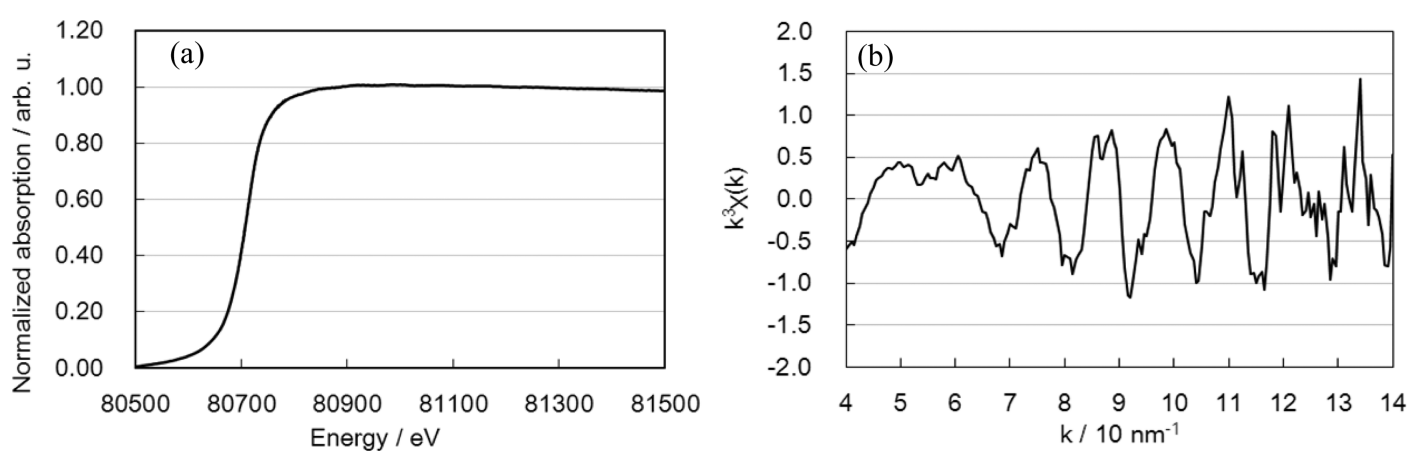

Figure 7. (a) Au K-edge spectrum for Au foil, and (b) $k^{3}$-weighted XAFS oscillation after background subtraction and normalization of spectrum (a).
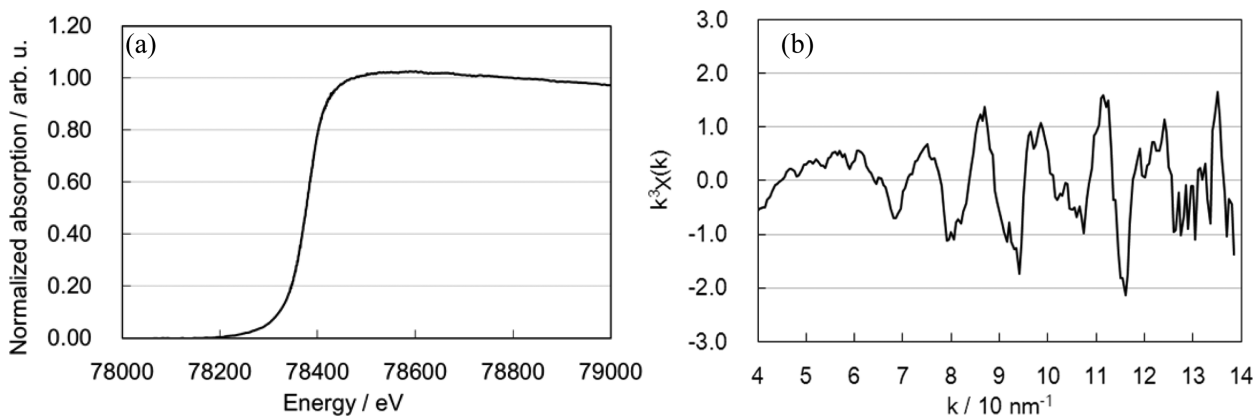

Figure 8. (a) Pt K-edge spectrum for Pt/Au (1/9) random alloy solid solution foil, and (b) $k^{3}$-weighted XAFS oscillation after background subtraction and normalization of spectrum (a).

smaller coordination number and the presence of nanoparticles. The coordination number and bond distance given in Table 2 have errors of 2.3 and $0.001 \mathrm{~nm}$, respectively. However, the bond distance obtained from a K-edge curve fitting was 0.004 $\mathrm{nm}$ longer than that for the $\mathrm{L}_{\mathrm{III}}$-edge. The longer distance from the K-edge analysis than that from the $\mathrm{L}_{3}$-edge corresponds to that found in the XAFS analyses of the Pt foil and Au foil.

3.3.3. Pt/Au/C Core-Shell Electrocatalyst. Figure 11a and b shows the Pt and Au K-edge $k^{3}$-weighted XAFS oscillations for
$\mathrm{Pt} / \mathrm{Au} / \mathrm{C}$. The Pt K-edge XAFS oscillations with $\mathrm{S} / \mathrm{N}>1$ were observed up to $120 \mathrm{~nm}^{-1}$, as shown in Figure 11a. As compared to $\mathrm{Pt}$ and $\mathrm{Au}$ K-edge XAFS, the oscillation of the Au K-edge was larger and lasted longer, which was more evident in the inversely Fourier filtered data in Figure S1 (Supporting Information). This means that $\mathrm{Au}$ had a larger coordination number and less disorder than Pt. The data were further analyzed by curve fitting to obtain structural parameters. Because the differences of phase shift and amplitude functions 

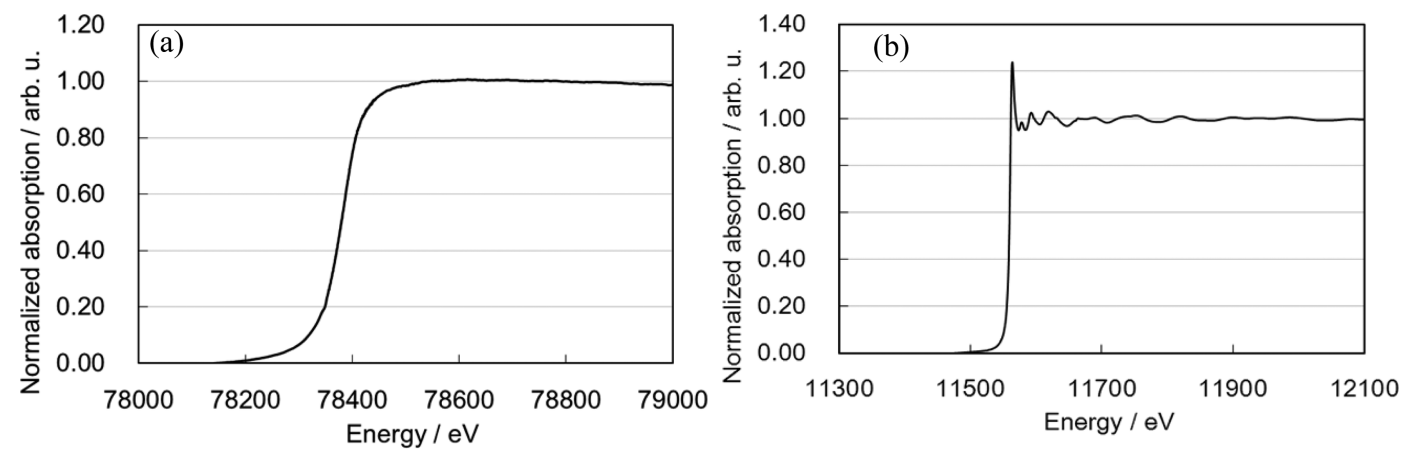

Figure 9. (a) Pt K-edge and (b) Pt $\mathrm{L}_{\mathrm{III}}$-edge XAFS spectra for Pt/C at $0.4 \mathrm{~V}$ vs RHE.
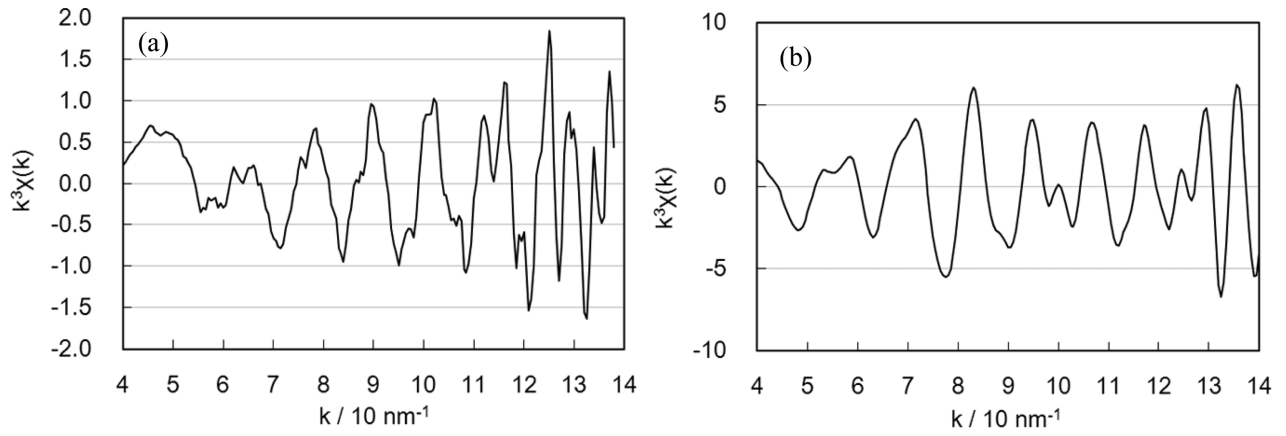

Figure 10. (a) Pt K-edge and (b) Pt $\mathrm{L}_{\mathrm{III}}$-edge $k^{3}$-weighted XAFS oscillations for $\mathrm{Pt} / \mathrm{C}$ at $0.4 \mathrm{~V}$ vs $\mathrm{RHE}$ after background subtraction and normalization of the spectrum in Figure 9.

Table 2. Curve-Fitting Results for Pt/C at $0.4 \mathrm{~V}$ vs RHE

\begin{tabular}{ccccc} 
sample & edge & bond & coordination number & interatomic distance/nm \\
$\mathrm{Pt} / \mathrm{C}$ & $\mathrm{Pt}-\mathrm{L}_{\mathrm{III}}$ & $\mathrm{Pt}-\mathrm{Pt}$ & $9.3 \pm 2.3$ & $0.273 \pm 0.001$ \\
& $\mathrm{Pt}-\mathrm{K}$ & $\mathrm{Pt}-\mathrm{Pt}$ & $9.6 \pm 2.0$ & $0.277 \pm 0.001$ \\
\hline
\end{tabular}
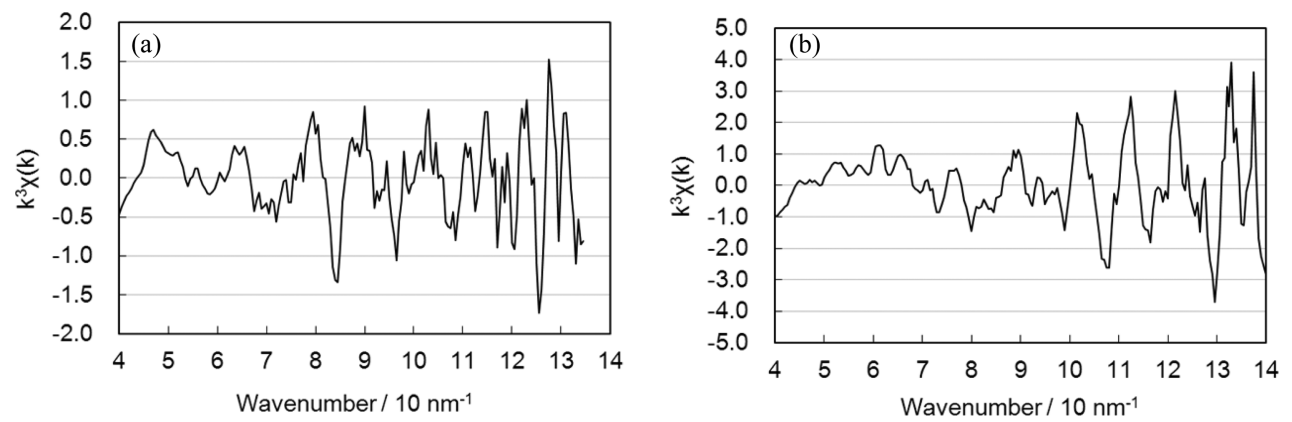

Figure 11. (a) Pt K-edge and (b) Au K-edge $k^{3}$-weighted XAFS oscillations of Pt/Au/C at $0.4 \mathrm{~V}$ vs RHE.

Table 3. Results from One-Shell Curve Fit for $\mathrm{Pt} / \mathrm{Au} / \mathrm{C}$

\begin{tabular}{ccccc}
\hline absorbing metal & scattering metal & coordination number & bond distance $/ \mathrm{nm}$ & Debye-Waller factor/nm \\
$\mathrm{Pt}$ & $\mathrm{Pt}$ & $6.8 \pm 1.2$ & $0.278 \pm 0.002$ & $0.0096 \pm 0.0006$ \\
$\mathrm{Au}$ & $\mathrm{Au}$ & $11.3 \pm 3.4$ & $0.280 \pm 0.002$ & $0.0072 \pm 0.0011$
\end{tabular}

are not so much in $\mathrm{Au}$ and $\mathrm{Pt}$, one-shell curve-fitting analyses of the $\mathrm{Pt}$ and $\mathrm{Au}$ K-edges were conducted for the $\mathrm{Pt}-\mathrm{Pt}$ and $\mathrm{Au}-$ $\mathrm{Au}$ bonds, respectively, to have an approximate image. The results are given in Table 3. The $\mathrm{Pt}-\mathrm{Pt}$ bond distance in the $\mathrm{Pt} / \mathrm{Au} / \mathrm{C}$ alloy was almost the same as that for $\mathrm{Pt} / \mathrm{C}$. However, the $\mathrm{Au}-\mathrm{Au}$ bond distance was shorter than that for the $\mathrm{Au}$ foil, and the contraction in bond distance was $0.006 \mathrm{~nm}$. In addition, the coordination number for $\mathrm{Au}-\mathrm{Au}$ was large (almost 12), which was close to that for the $\mathrm{Au}$ foil and was significantly different from that for $\mathrm{Au}$ nanoclusters. In contrast, the coordination number for $\mathrm{Pt}-\mathrm{Pt}$ was around 6 . These coordination numbers are consistent with the core-shell model, in which more $\mathrm{Pt}$ than $\mathrm{Au}$ is on the surface.

To probe the structures in more detail, two-shell curve-fitting analyses for $\mathrm{Pt}$ and $\mathrm{Au} \mathrm{K}$-edges were conducted. To reduce the number of fitting parameters, values of $\Delta E_{0}$ for $\mathrm{Au}-\mathrm{Au}, \mathrm{Pt}-\mathrm{Pt}$, and $\mathrm{Pt}-\mathrm{Au}$ were fixed to those for the corresponding foils, and the value of $\Delta E_{0}$ for $\mathrm{Au}-\mathrm{Pt}$ was fixed at $5.0 \mathrm{eV}$. The uncertainty 
Table 4. Results from Two-Shell Curve Fits for Pt/Au/C

\begin{tabular}{|c|c|c|c|c|c|c|}
\hline \multirow[b]{2}{*}{ absorber } & \multicolumn{3}{|c|}{ scattering metal Pt } & \multicolumn{3}{|c|}{ scattering metal Au } \\
\hline & $N$ & $r / \mathrm{nm}$ & $\mathrm{DW} / \mathrm{nm}$ & $N$ & $r / \mathrm{nm}$ & $\mathrm{DW} / \mathrm{nm}$ \\
\hline Pt & $7.2 \pm 2.9$ & $0.275 \pm 0.003$ & $0.0097 \pm 0.0006$ & $2.0 \pm 0.8$ & $0.279 \pm 0.004$ & $0.008 \pm 0.001$ \\
\hline $\mathrm{Au}$ & $2.7 \pm 2.7$ & $0.279 \pm 0.005$ & $0.005 \pm 0.001$ & $9.7 \pm 2.9$ & $0.282 \pm 0.003$ & $0.007 \pm 0.001$ \\
\hline
\end{tabular}
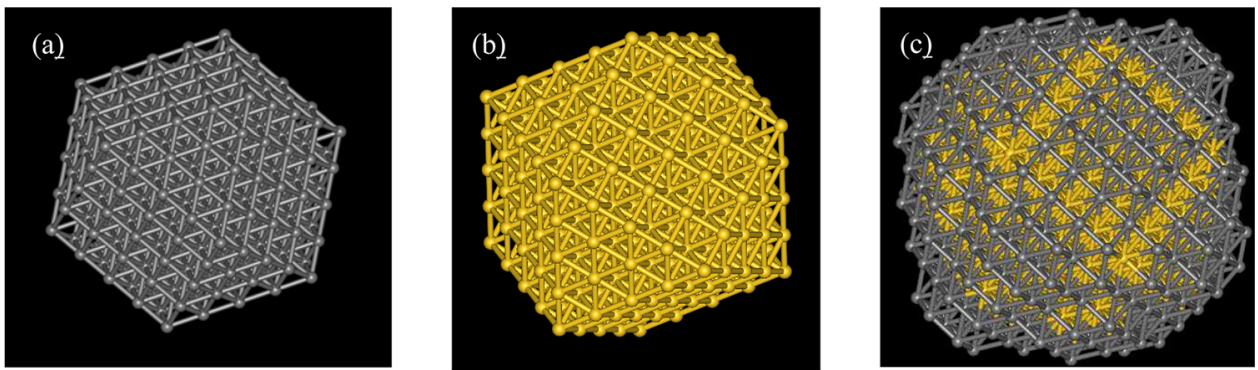

Figure 12. Estimated structures of (a) Pt cuboctahedron, (b) Au cuboctahedron, and (c) Pt/Au core-shell particle.

$( \pm 10 \mathrm{eV})$ in $\Delta E_{0}$ for the $\mathrm{Au}-\mathrm{Pt}$ bond gave rise to errors in bond lengths of approximately $1 \%$. Table 4 shows the structural parameters obtained from the curve-fitting analysis. The bond distances and coordination numbers of $\mathrm{Pt}-\mathrm{Au}$ and $\mathrm{Au}-\mathrm{Pt}$ obtained from $\mathrm{Pt}$ and Au K-edge fits satisfied the conditions given in eqs 6 and 7 within the error. The distance for $\mathrm{Pt}-\mathrm{Au}$ was longer than that for $\mathrm{Pt}-\mathrm{Pt}$ obtained from the one-shell curve fit. The $\mathrm{Au}-\mathrm{Au}$ bond distance from the two-shell curve fit was longer than that from the one-shell fit. This can be explained by the presence of $\mathrm{Au}-\mathrm{Pt}$ bonding, which should have a bond length between those of $\mathrm{Pt}-\mathrm{Pt}$ and $\mathrm{Au}-\mathrm{Au}$. The $\mathrm{Au}-\mathrm{Au}$ distance was shorter than that for the $\mathrm{Au}$ foil, and the total coordination number of $\mathrm{Au}-\mathrm{Au}+\mathrm{Au}-\mathrm{Pt}=12.4$ was close to that expected from the model of the Au core. However, the total coordination number of $\mathrm{Pt}-\mathrm{Au}+\mathrm{Pt}-\mathrm{Pt}(=9.2)$ was much smaller than that for the $\mathrm{Pt}$ foil; these coordination numbers demonstrate the $\mathrm{Pt}$ shell/Au core structure. As discussed later, the "two-shell $\mathrm{Pt}$ on $\mathrm{Au}$ core" model nanocluster with a diameter of $3.0 \mathrm{~nm}$ provided a total coordination number of 8.7 , which corresponds to the observed value.

\section{DISCUSSION}

4.1. Estimation of $\mathrm{Pt} / \mathrm{C}$ and $\mathrm{Pt} / \mathrm{Au} / \mathrm{C}$ Core-Shell Electrocatalyst Structures. 4.1.1. Estimation of the Pt/C Nanocluster Structure. There are two possible structures in nanoclusters, icosahedral and cuboctahedral in the literature. Judging from the particle size, we assumed the cuboctahedral structure in this Article. ${ }^{55}$ On the basis of an average diameter of $2.2 \mathrm{~nm}$ and the cuboctahedron model, the particles have 4atom edges (1.9 $\mathrm{nm}$ in diameter, 147 atoms) or 5-atom edges (2.4 $\mathrm{nm}$ in diameter, 309 atoms). Figure 12a shows a 309-atom cuboctahedron with 5 -atom edges. The average coordination numbers for all $\mathrm{Pt}$ atoms calculated from the 4-atom edge and 5-atom edge models were 9.0 and 9.6, respectively, which are in good agreement with those obtained from the K-edge $/ \mathrm{L}_{\mathrm{III}}$-edge XAFS curve fit given in Table $2(9.6 \pm 2.0$ and $9.3 \pm 2.3$, respectively). Therefore, the Pt-on-carbon nanocluster was a cuboctahedron structure with 4-atom or 5-atom edges.

4.1.2. Estimation of the Pt/Au/C Structure. The XAFS results revealed that the coordination number derived from $\mathrm{Au}$ K-edge EXAFS oscillations was larger than that derived from the Pt K-edge data, which indicates a structure composed of a Au-rich core and a Pt-rich shell. Although Strbac et al. suggested that the $\mathrm{Au}(111)$ single crystal was partially covered with $\mathrm{Pt},{ }^{56}$ the total coordination number of Au was almost 12, which indicates that the $\mathrm{Au}$ nanoparticle was almost fully covered with Pt. Cyclic voltammetry also showed that mostly Pt occupied the surface of the nanocluster surface. Although the reaction mechanism of $\mathrm{H}_{2} \mathrm{PtCl}_{6}$ with the Au nanoparticle is still unknown, a Pt shell can be easily prepared around the Au core by this simple reaction.

The $\mathrm{Pt} / \mathrm{Au}$ core-shell structure was further analyzed on the basis of the XAFS, ICP, and TEM data. ICP analysis showed that the bulk $\mathrm{Au}: \mathrm{Pt}$ ratio was 1.1. From the particle sizes of $\mathrm{Au}$ and $\mathrm{Pt} / \mathrm{Au}$ (2.6 and $3.0 \mathrm{~nm}$, respectively), we propose a cuboctahedral model with 659 atoms, as shown in Figure 12. In this structure, $309 \mathrm{Au}$ atoms are located inside the nanocluster, while $350 \mathrm{Pt}$ atoms cover the $\mathrm{Au}$ nanoclusters in two layers. The estimated core-shell model is shown in Figure 12c.

The coordination numbers of the $\mathrm{Pt} / \mathrm{Au}$ structure in Figure $12 \mathrm{c}$ are given in Table 5. The coordination numbers obtained

Table 5. Coordination Numbers of Estimated $\mathrm{Pt} / \mathrm{Au} / \mathrm{C}$ Structure

\begin{tabular}{ccc} 
& \multicolumn{2}{c}{ coordination number } \\
\cline { 2 - 3 } absorbing metal & scattering metal Pt & scattering metal Au \\
\hline $\mathrm{Pt}$ & 6.7 & 2.1 \\
$\mathrm{Au}$ & 2.3 & 9.6 \\
\hline
\end{tabular}

from the curve fits in Table 4 correspond to those observed. Thus, we propose the model structure shown in Figure 12c, where the Au core is covered with two layers of Pt atoms.

4.2. Bond Length and Electrochemical Activity of Pt/ $\mathrm{Au} / \mathrm{C}$. Table 4 shows that the $\mathrm{Au}-\mathrm{Au}$ and $\mathrm{Pt}-\mathrm{Pt}$ distances for the $\mathrm{Pt} / \mathrm{Au} / \mathrm{C}$ core-shell electrocatalyst were shorter than the corresponding distances in the $\mathrm{Au}$ and $\mathrm{Pt}$ foils. The $\mathrm{Pt}-\mathrm{Pt}$ distance in $\mathrm{Pt} / \mathrm{C}$ was slightly shorter than that in the $\mathrm{Pt}$ foil, as shown in Table 3. The Pt-Pt distance for $\mathrm{Pt} / \mathrm{Au} / \mathrm{C}$ was even smaller than that for $\mathrm{Pt} / \mathrm{C}$. The $\mathrm{Au}-\mathrm{Au}$ bond distance in the $\mathrm{Pt} / \mathrm{Au} / \mathrm{C}$ was also shorter than that in the $\mathrm{Au}$ foil. $\mathrm{Pt}$ and $\mathrm{Au}$ atoms generally form fcc lattices, where the Pt lattice constant is smaller than that of the Au lattice; therefore, a Pt atomic layer on a $\mathrm{Au}$ lattice is expected to have elongated $\mathrm{Pt}-\mathrm{Pt}$ distances due to the influence of the Au lattice. This expansion of the Pt$\mathrm{Pt}$ distance was observed in epitaxially grown $\mathrm{Pt}$ on a $\mathrm{Au}(111)$ 
surface ${ }^{34}$ However, the Pt-Pt distance obtained for the twoshell curve fitting was not elongated, but instead the $\mathrm{Au}-\mathrm{Au}$ distance was largely contracted. This is due to the strong $\mathrm{Pt}-\mathrm{Pt}$ bond, which induces contraction of the Au core. This may be due to the labile properties of nanoclusters.

According to Adzic et al. ${ }^{25}$ and Mukerjee et al., ${ }^{57}$ shorter PtPt distances contribute to enhanced area-specific activity for the ORR. A comparison of the $\mathrm{Pt}-\mathrm{Pt}$ distance obtained in $\mathrm{Pt} / \mathrm{Au} /$ $\mathrm{C}$ with the relationship between the $\mathrm{Pt}-\mathrm{Pt}$ distance and ORR area-specific activity reported by Mukerjee et al. ${ }^{57}$ indicates that the $\mathrm{Pt}-\mathrm{Pt}$ distance found in $\mathrm{Pt} / \mathrm{Au} / \mathrm{C}$ was in the range that can explain the high area-specific activity. The XAFS results suggest the core-shell structure and contraction of the $\mathrm{Pt}-\mathrm{Pt}$ distances, which are considered to be related to the high ORR area-specific activity in the $\mathrm{Pt} / \mathrm{Au} / \mathrm{C}$ core-shell electrocatalysts. The $\mathrm{Pt}-\mathrm{Au}$ nanocluster has an unexpected structure; that is, the $\mathrm{Pt}-\mathrm{Pt}$ distance is shorter than that of $\mathrm{Pt}$ foil. The $\mathrm{Pt}$ $\mathrm{L}_{\mathrm{III}}$ edge $\mathrm{X}$-ray near edge structure was measured and showed a larger d-vacancy than those for $\mathrm{Pt}$ foil and $\mathrm{Pt} / \mathrm{C}$, as shown in Figure S2 (Supporting Information). This is another unexpected result because electron transfer from $\mathrm{Au}$ to $\mathrm{Pt}$ should occur. The $\mathrm{Pt} \mathrm{L}_{\mathrm{III}}$ edge for $\mathrm{Pt}-\mathrm{Au}$ foil shows a smaller $\mathrm{d}$ vacancy by electron transfer from $\mathrm{Au}$, as shown in Figure S2 (Supporting Information). We are now preparing another report to discuss the electronic structure and activity of $\mathrm{Pt}-\mathrm{M}$ alloys. However, we can confirm that the $\mathrm{Pt} / \mathrm{Au}$ nanoparticle should have a structure and electronic properties different from those of Pt deposited on a Au surface and PtAu bulk alloy.

\section{CONCLUSIONS}

A carbon-supported Pt-shell Au-core electrocatalyst $(\mathrm{Pt} / \mathrm{Au} / \mathrm{C})$ was prepared by sequential deposition of $\mathrm{Pt}$ ions on the surface of $\mathrm{Au}$ nanoclusters. The nanoclusters were prepared by the sputter-deposition-onto-ionic-liquid method and supported on carbon. The ORR area-specific activity for the prepared $\mathrm{Pt} / \mathrm{Au} /$ $\mathrm{C}$ in $0.1 \mathrm{M} \mathrm{HClO}_{4}$ aqueous solution was approximately 2 times higher than that of a commercial carbon-supported $\mathrm{Pt} / \mathrm{C}$ electrocatalyst. The $\mathrm{Pt} / \mathrm{Au}$ core-shell structure was confirmed by electrochemical methods and XAFS analysis. The $\mathrm{Pt}-\mathrm{Pt}$ bond distance for $\mathrm{Pt} / \mathrm{Au} / \mathrm{C}$ obtained from the XAFS analysis was not elongated by interactions with the $\mathrm{Au}$ atoms in the core. Instead, the Pt-Pt bond distance was slightly contracted, even compared to that of $\mathrm{Pt} / \mathrm{C}$. The core-shell structure and the contraction of the $\mathrm{Pt}-\mathrm{Pt}$ distance on the $\mathrm{Au}$ core must cause high area-specific activity.

\section{ASSOCIATED CONTENT}

\section{(S) Supporting Information}

Curve-fitting results of $\mathrm{Pt}$ and $\mathrm{Au}$ K-edge of $\mathrm{Pt} / \mathrm{Au} / \mathrm{C}$ and amount of $\mathrm{d}$ vacancy in $\mathrm{Pt}$ of $\mathrm{Pt} / \mathrm{Au} / \mathrm{C}$. This material is available free of charge via the Internet at http://pubs.acs.org.

\section{AUTHOR INFORMATION}

\section{Corresponding Author}

*Tel.: +81-11-706-9113. E-mail: askr@cat.hokudai.ac.jp.

\section{Notes}

The authors declare no competing financial interest.

\section{ACKNOWLEDGMENTS}

We express thanks to Mr. K. Onishi for the preparation of the $\mathrm{Au}$ nanoclusters and to Nissan ARC for their help with XAFS measurements.

\section{REFERENCES}

(1) Srinivasan, S.; Miller, E. Applications and economics of fuel cell power plants/power sources. In Fuel Cells; Srinivasan, S., Ed.; Springer: New York, 2006; pp 575-605.

(2) Gasteiger, H. A.; Kocha, S. S.; Sompalli, B.; Wagner, F. T. Activity Benchmarks and Requirements for Pt, Pt-Alloy, and Non-Pt Oxygen Reduction Catalysts for PEMFCs. Appl. Catal., B: Environ. 2005, 56, 9-35.

(3) Tarasevich, M. R.; Sadkowski, A.; Yeager, E. Oxygen electrochemistry. In Comprehensive Treatise of Electrochemistry; Conway, B. E., Bockris, J. O., Yeager, E., Khan, S. U. M., White, R. E., Eds.; Plenum Press: New York, 1983; Vol. 7, pp 301-398.

(4) Adzic, R. R. Recent advances in the kinetics of oxygen reduction. In Electrocatalysis; Lipkowski, J., Ross, P. N., Eds.; Wiley-VCH: New York, 1998; p 197.

(5) Gottesfeld, S.; Zawodzinski, T. A. Polymer Electrolyte Fuel Cells. In Advances in Electrochemical Science and Engineering; Alkire, R. C., Kolb, D. M., Charles, W. T., Eds.; Wiley-VCH Verlag GmbH: New York, 2008; Vol. 5, pp 195-301.

(6) Brankovic, S. R.; Wang, J. X.; Adzic, R. R. New Methods of Controlled Monolayer-to-Multilayer Deposition of Pt for Designing Electrocatalysts at an Atomic Level. J. Serb. Chem. Soc. 2001, 66, 887898.

(7) Wang, J. X.; Markovic, N. M.; Adzic, R. R. Kinetic Analysis of Oxygen Reduction on $\mathrm{Pt}(111)$ in Acid Solutions: Intrinsic Kinetic Parameters and Anion Adsorption Effects. J. Phys. Chem. B 2004, 108, 4127-4133.

(8) Lytle, F. W.; Via, G. H.; Sinfelt, J. H. New Application of Extended X-ray Absorption Fine Structure (EXAFS) as a Surface Probe-Nature of Oxygen Interaction with a Ruthenium Catalyst. J. Chem. Phys. 1977, 67, 3831-3832.

(9) Van't Blik, H. F. J.; Prins, R. Characterization of Supported Cobalt and Cobalt-Rhodium Catalysts: I. Temperature-Programmed Reduction (TPR) and Oxidation (TPO) of Co $\mathrm{RhAl}_{2} \mathrm{O}_{3}$. J. Catal. 1986, 97, 188-199.

(10) Iwasawa, Y.; Asakura, K.; Ishii, H.; Kuroda, H. Dynamic Behaviour of Active Sites of a $\mathrm{SiO}_{2}$-Attached $\mathrm{Mo}$ (VI)-Dimer Catalyst during Ethanol Oxidation Observed by Means of EXAFS. Z. Phys. Chem. 1985, 144, 105-115.

(11) Asakura, K.; Kitamura-Bando, K.; Isobe, K.; Arakawa, H.; Iwasawa, Y. Metal-Assisted CO Insertion Reaction on a New Surface Rhodium Dimer Catalyst Observed by an in Situ EXAFS Technique. J. Am. Chem. Soc. 1990, 112, 3242-3244.

(12) Allen, P. G.; Conradson, S. D.; Wilson, M. S.; Gottesfeld, S.; Raistrick, I. D.; Valerio, J.; Lovato, M. In Situ Structural Characterization of a Platinum Electrocatalyst by Dispersive X-ray Absorption Spectroscopy. Electrochim. Acta 1994, 39, 2415-2418.

(13) Allen, P. G.; Conradson, S. D.; Wilson, M. S.; Gottesfeld, S.; Raistrick, I. D.; Valerio, J.; Lovato, M. Direct Observation of Surface Oxide Formation and Reduction on Platinum Clusters by TimeResolved X-ray Absorption Spectroscopy. J. Electroanal. Chem. 1995, 384, 99-103.

(14) Wiltshire, R. J. K.; King, C. R.; Rose, A.; Wells, P. P.; Hogarth, M. P.; Thompsett, D.; Russell, A. E. A PEM Fuel Cell for in Situ XAS Studies. Electrochim. Acta 2005, 50, 5208-5217.

(15) Ishiguro, N.; Saida, T.; Uruga, T.; Nagamatsu, S.-i.; Sekizawa, O.; Nitta, K.; Yamamoto, T.; Ohkoshi, S.-i.; Iwasawa, Y.; Yokoyama, T.; Tada, M. Operando Time-Resolved X-ray Absorption Fine Structure Study for Surface Events on a $\mathrm{Pt}_{3} \mathrm{Co} / \mathrm{C}$ Cathode Catalyst in a Polymer Electrolyte Fuel Cell during Voltage-Operating Processes. ACS Catal. 2012, 1319-1330.

(16) Yoshitake, H.; Mochizuki, T.; Yamazaki, O.; Ota, K.-I. Study of the Density of the D-State and Structure Transformation of Pt Fine Particles Dispersed on Carbon Electrodes by in Situ X-ray Absorption Spectroscopy. J. Electroanal. Chem. 1993, 361, 229-237.

(17) Yoshitake, H.; Yamazaki, O.; Ota, K.-I. Novel Spectroelectrochemical Cell for in-Situ XAFS Spectroscopy on Gas Generating Electrodes. J. Electroanal. Chem. 1994, 371, 287-290. 
(18) Mukerjee, S.; Srinivasan, S.; Soriaga, M. P.; McBreen, J. Effect of Preparation Conditions of Pt Alloys on Their Electronic, Structural, and Electrocatalytic Activities for Oxygen Reduction: XRD, XAS, and Electrochemical Studies. J. Phys. Chem. 1995, 99, 4577-4589.

(19) McBreen, J.; Mukerjee, S. In Situ X-Ray Absorption Studies of a Pt-Ru Electrocatalyst. J. Electrochem. Soc. 1995, 142, 3399-3404.

(20) Mukerjee, S.; McBreen, J. Effect of Particle Size on the Electrocatalysis by Carbon-Supported Pt Electrocatalysts: an in Situ XAS Investigation. J. Electroanal. Chem. 1998, 448, 163-171.

(21) Maniguet, S.; Mathew, R. J.; Russell, A. E. EXAFS of Carbon Monoxide Oxidation on Supported Pt Fuel Cell Electrocatalysts. J. Phys. Chem. B 2000, 104, 1998-2004.

(22) Russell, A. E.; Rose, A. X-ray Absorption Spectroscopy of Low Temperature Fuel Cell Catalysts. Chem. Rev. 2004, 104, 4613-4636.

(23) Imai, H.; Izumi, K.; Matsumoto, M.; Kubo, Y.; Kato, K.; Imai, Y. In Situ and Real-Time Monitoring of Oxide Growth in a Few Monolayers at Surfaces of Platinum Nanoparticles in Aqueous Media. J. Am. Chem. Soc. 2009, 131, 6293-6300.

(24) Sasaki, K.; Wang, J. X.; Naohara, H.; Marinkovic, N.; More, K.; Inada, H.; Adzic, R. R. Recent Advances in Platinum Monolayer Electrocatalysts for Oxygen Reduction Reaction: Scale-Up Synthesis, Structure and Activity of Pt Shells on Pd Cores. Electrochim. Acta 2010, 55, 2645-2652.

(25) Adzic, R. R.; Zhang, J.; Sasaki, K.; Vukmirovic, M. B.; Shao, M.; Wang, J. X.; Nilekar, A. U.; Mavrikakis, M.; Valerio, J. A.; Uribe, F. Platinum Monolayer Fuel Cell Electrocatalysts. Top. Catal. 2007, 46, 249-262.

(26) Kristian, N.; Wang, X. Ptshell-Aucore/C electrocatalyst with a controlled shell thickness and improved Pt utilization for fuel cell reactions. Electrochem. Commun. 2008, 10, 12-15.

(27) Shuangyin, W.; Noel, K.; Sanping, J.; Xin, W. Controlled Synthesis of Dendritic Au@Pt Core-Shell Nanomaterials for Use as an Effective Fuel Cell Electrocatalyst. Nanotechnology 2009, 20, 025605.

(28) Luo, J.; Wang, L.; Mott, D.; Njoki, P. N.; Lin, Y.; He, T.; Xu, Z.; Wanjana, B. N.; Lim, I. I. S.; Zhong, C. J. Core/Shell Nanoparticles as Electrocatalysts for Fuel Cell Reactions. Adv. Mater. 2008, 20, 43424347.

(29) Zheng, J.; Yang, J.; Lee, J. Y.; Zhou, W. Preparation of CarbonSupported Core-Shell Au-Pt Nanoparticles for Methanol Oxidation Reaction: The Promotional Effect of the Au Core. J. Phys. Chem. B 2006, 110, 24606-24611.

(30) Nagamatsu, S.-i.; Arai, T.; Yamamoto, M.; Ohkura, T.; Oyanagi, H.; Ishizaka, T.; Kawanami, H.; Uruga, T.; Tada, M.; Iwasawa, Y. Potential-Dependent Restructuring and Hysteresis in the Structural and Electronic Transformations of $\mathrm{Pt} / \mathrm{C}, \mathrm{Au}(\mathrm{Core})-\mathrm{Pt}($ Shell $) / \mathrm{C}$, and $\mathrm{Pd}($ Core $)-\mathrm{Pt}($ Shell)/C Cathode Catalysts in Polymer Electrolyte Fuel Cells Characterized by in Situ X-ray Absorption Fine Structure. J. Phys. Chem. C 2013, 117, 13094-13107.

(31) Xiu, C.; Shengnan, W.; Scott, J.; Zhibing, C.; Zhenghua, W.; Lun, W.; Yongxin, L. The Deposition of Au-Pt Core-Shell Nanoparticles on Reduced Graphene Oxide and their Catalytic Activity. Nanotechnology 2013, 24, 295402.

(32) Inaba, M.; Tsuji, H. Platinum Core-Shell Catalyst Manufacturing Method, and Fuel Cell using Catalyst. Japan Patent WO2011115012 A1, March 19, 2010.

(33) Tsuji, H.; Kaneko, A.; Banno, M.; Yamada, H.; Saito, M.; Tasaka, A.; Inaba, M. A Novel Technique for Preparation of Pt shell/ $\mathrm{Au}$ core/C Core-Shell Catalysts and Their Activity for Oxygen Reduction Reaction. 218th ECS Meeting Abstracts; Las Vegas, 2010; MA2010-02, p 858.

(34) Shibata, M.; Hayashi, N.; Sakurai, T.; Kurokawa, A.; Fukumitsu, H.; Masuda, T.; Uosaki, K.; Kondo, T. Electrochemical Layer-by-Layer Deposition of Pseudomorphic Pt Layers on $\mathrm{Au}(111)$ Electrode Surface Confirmed by Electrochemical and In Situ Resonance Surface X-ray Scattering Measurements. J. Phys. Chem. C 2012, 116, 26464-26474.

(35) Zhang, J.; Sasaki, K.; Sutter, E.; Adzic, R. R. Stabilization of Platinum Oxygen-Reduction Electrocatalysts Using Gold Clusters. Science 2007, 315, 220-222.
(36) Nagamatsu, S.-i.; Arai, T.; Yamamoto, M.; Ohkura, T.; Oyanagi, H.; Ishizaka, T.; Kawanami, H.; Uruga, T.; Tada, M.; Iwasawa, Y. Potential-Dependent Restructuring and Hysteresis in the Structural and Electronic Transformations of $\mathrm{Pt} / \mathrm{C}, \mathrm{Au}$ (Core)-Pt(Shell)/C, and $\mathrm{Pd}($ Core)-Pt(Shell)/C Cathode Catalysts in Polymer Electrolyte Fuel Cells Characterized by in Situ X-ray Absorption Fine Structure. J. Phys. Chem. C 2013, 117, 13094-13107.

(37) Asakura, K.; Satow, Y.; Kuroda, H. Ce K-edge EXAFS Spectrum of $\mathrm{CeO}_{2}$. J. Phys. (Paris) 1986, 47, 185-188.

(38) Nishihata, Y.; Emura, S.; Maeda, H.; Kubozono, Y.; Harada, M.; Uruga, T.; Tanida, H.; Yoneda, Y.; Mizuki, J.; Emoto, T. XAFS Spectra in the High-Energy Region Measured at SPring-8. J. Synchrotron Radiat. 1999, 6, 149-151.

(39) Nagamatsu, S.-I.; Arai, T.; Yamamoto, M.; Oyanagi, H.; Daimaru, A.; Ishizaka, T.; Kawanami, H.; Uruga, T.; Tada, M.; Iwasawa, Y. In Situ XAFS Study on PEFC Catalysts: Structure and Behavior of Pt-M/C $(\mathrm{M}=\mathrm{Au}, \mathrm{Pd})$ in the Stepwise Voltage Operation. 220th ECS Meeting Abstracts, Boston, 2011; MA2011-02, p 1055.

(40) Kaito, T.; Mitsumoto, H.; Sugawara, S.; Shinohara, K.; Uehara, H.; Ariga, H.; Takakusagi, S.; Asakura, K. A New Spectroelectrochemical Cell for in Situ Measurement of $\mathrm{Pt}$ and $\mathrm{Au} \mathrm{K}$-edge X-ray Absorption Fine Structure. Rev. Sci. Instrum., submitted.

(41) Torimoto, T.; Okazaki, K.-I.; Kiyama, T.; Hirahara, K.; Tanaka, N.; Kuwabata, S. Sputter Deposition onto Ionic Liquids: Simple and Clean Synthesis of Highly Dispersed Ultrafine Metal Nanoparticles. Appl. Phys. Lett. 2006, 89, 243117-3.

(42) Hatakeyama, Y.; Takahashi, S.; Nishikawa, K. Can Temperature Control the Size of Au Nanoparticles Prepared in Ionic Liquids by the Sputter Deposition Technique? J. Phys. Chem. C 2010, 114, 1109811102.

(43) Hatakeyama, Y.; Onishi, K.; Nishikawa, K. Effects of Sputtering Conditions on Formation of Gold Nanoparticles in Sputter Deposition Technique. RSC Adv. 2011, 1, 1815-1821.

(44) Cook, J. J. W.; Sayers, D. E. Criteria for Automatic X-ray Absorption Fine Structure Background Removal. J. Appl. Phys. 1981, 52, 5024-5031.

(45) Asakura, K. Analysis of XAFS. In X-ray Absorption Fine Structure for Catalysts and Surfaces; Iwasawa, Y., Ed.; World Scientific: Singapore, 1996; pp 35-58.

(46) Rehr, J. J.; Albers, R. C. Theoretical Approaches to X-ray Absorption Fine Structure. Rev. Mod. Phys. 2000, 72, 621-654.

(47) Teo, B. K.; Antonio, M. R.; Averill, B. A. Molybdenum K-edge Extended X-ray Absorption Fine Structure Studies of Synthetic Molybdenum-Iron-Sulfur Clusters Containing the MoS4 Unit: Development of a Fine Adjustment Technique Based on Models. J. Am. Chem. Soc. 1983, 105, 3751-3762.

(48) Toshima, N.; Harada, M.; Yonezawa, T.; Kushihashi, K.; Asakura, K. Structural Analysis of Polymer-Protected Palladium/ Platinum Bimetallic Clusters as Dispersed Catalysts by Using Extended X-ray Absorption Fine Structure Spectroscopy. J. Phys. Chem. 1991, 95, 7448-7453.

(49) Toshima, N.; Harada, M.; Yamazaki, Y.; Asakura, K. Catalytic Activity and Structural Analysis of Polymer-Protected Gold-Palladium Bimetallic Clusters Prepared by the Simultaneous Reduction of Hydrogen Tetrachloroaurate and Palladium Dichloride. J. Phys. Chem. 1992, 96, 9927-9933.

(50) Via, G. H.; Drake, K. F.; Meitzner, G.; Lytle, F. W.; Sinfelt, J. H. Analysis of EXAFS Data on Bimetallic Clusters. Catal. Lett. 1990, 5, $25-33$.

(51) Hamilton, W. Significance Tests on the Crystallographic R Factor. Acta Crystallogr. 1965, 18, 502-510.

(52) Li, W.; Lane, A. M. Resolving the HUPD and HOPD by DEMS to Determine the ECSA of Pt Electrodes in PEM Fuel Cells. Electrochem. Commun. 2011, 13, 913-916.

(53) Tremiliosi-Filho, G.; Dall'Antonia, L. H.; Jerkiewicz, G. Growth of Surface Oxides on Gold Electrodes under Well-Defined Potential, Time and Temperature Conditions. J. Electroanal. Chem. 2005, 578, $1-8$. 
(54) Anastasijević, N. A.; Vesović, V.; Adžić, R. R. Determination of the Kinetic Parameters of the Oxygen Reduction Reaction Using the Rotating Ring-Disk Electrode: Part I. Theory. J. Electroanal. Chem. Interfacial Electrochem. 1987, 229, 305-316.

(55) Baletto, F.; Ferrando, R. Structural Properties of Nanoclusters: Energetic, Thermodynamic, and Kinetic Effects. Rev. Mod. Phys. 2005, 77, 371-423.

(56) Strbac, S.; Petrovic, S.; Vasilic, R.; Kovac, J.; Zalar, A.; Rakocevic, Z. Carbon monoxide oxidation on $\mathrm{Au}(111)$ surface decorated by spontaneously deposited Pt. Electrochim. Acta 2007, 53, 998-1005.

(57) Mukerjee, S.; Srinivasan, S.; Soriaga, M. P.; McBreen, J. Role of Structural and Electronic Properties of $\mathrm{Pt}$ and $\mathrm{Pt}$ Alloys on Electrocatalysis of Oxygen Reduction. J. Electrochem. Soc. 1995, 142, $1409-1422$. 